\title{
Treatment Outcomes in Hairy Cell Leukemia: Data of Patients in a Tertiary Referral Hospital in Turkey for Over 20 Years
}

\author{
Tüylü Hücreli Lösemide Tedavi Sonuçları: Türkiye'deki Üçüncü Basamak Bir \\ Hastanede 20 Yıldan Fazla Hastaya Ait Veriler
}

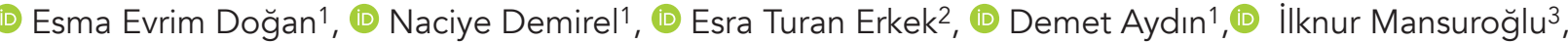 \\ (D) Melda Cömert Özkan4, (D) Rafet Eren ${ }^{1}$ \\ ${ }^{1}$ University of Health Sciences Turkey, Prof. Dr. Cemil Taşcıoğlu City Hospital, Clinic of Hematology, Istanbul, Turkey \\ ${ }^{2}$ University of Health Sciences Turkey, Kartal Lütfü Kırdar City Hospital, Clinic of Hematology, Istanbul, Turkey \\ 3 University of Health Sciences Turkey, Prof. Dr. Cemil Taşcıoğlu City Hospital, Clinic of Pathology, Istanbul, Turkey \\ ${ }^{4}$ University of Health Sciences Turkey, Gülhane Training and Research Hospital, Clinic of Hematology, Ankara, Turkey
}

\begin{abstract}
Objective: To share our clinical experience on the first, second, and third-line treatments of hairy cell leukemia (HCL), with cladribine and other methods, including splenectomy and interferon treatments.

Methods: The clinical features, treatments (including response and complications), and survival data of 24 patients, who were diagnosed with HCL at Okmeydanı Training and Research Hospital between November 1996 and August 2019, were retrospectively analyzed.

Results: The mean follow-up time was $130.77 \pm 75.07$ months. All patients who had received cladribine as a first-line treatment ( $\mathrm{n}=17$ ) demonstrated response to treatment, whereas complete response (CR) was observed in $41.2 \%$. Mean progression-free survival after the first-line treatment was $83.58 \pm 57.40$ months and median survival was 75.25 months (minimum-maximum: 2.14-194.79). Progression-free survival time was significantly longer in cladribine recipients.

Conclusion: The effectiveness of cladribine in HCL treatment was once more shown in this study; however, the low frequency of CR to cladribine in our study compared to the literature was considered to be related to the increased frequency of massive splenomegaly and lymphadenopathy at the time of diagnosis, as well as low platelet values.
\end{abstract}

Keywords: Cladribine, hairy cell leukemia, treatment, survival

\section{öz}

Amaç: Tüylü hücreli löseminin (HCL) kladribin ve splenektomi ile interferon tedavileri gibi diğer yöntemlerle birinci, ikinci ve üçüncü basamak tedavileriyle ilgili klinik deneyimimizi paylaşmaktır.

Gereç ve Yöntem: Okmeydanı Eğitim ve Araştırma Hastanesi'nde Kasım 1996 ile Ağustos 2019 tarihleri arasında HCL tanısı alan 24 hastanın klinik özellikleri, tedavileri (yanıt ve komplikasyonlar dahil) ve sağkalım verileri geriye dönük olarak incelendi.

Bulgular: Ortalama takip süresi 130,77 $\pm 75,07$ aydı. Birinci basamak tedavi olarak kladribin alan tüm hastalar ( $\mathrm{n}=17)$ tedaviye yanıt gösterdi ve \%41,2'sinde tam yanıt gözlendi. İlk basamak tedaviden sonra ortalama progresyonsuz sağkalım $83,58 \pm 57,40$ aydı ve medyan sağkalım 75,25 aydı (en küçük-en büyük: 2,14-194,79). Kladribin kullanan hastalarda progresyonsuz sağkalım süresinin anlamlı düzeyde daha uzun olduğu bulunmuştur.

Sonuç: Bu çalışmada kladribinin HCL tedavisinde etkinliği bir kez daha gösterilmiş olsa da, kladribine tam yanıt sıklığının literatüre göre düşük olması, tanıdaki masif splenomegali ve lenfadenopati sıklığının fazla olması ve düşük trombosit değeri ile ilişkili olduğu düşünülmüştür.

Anahtar Kelimeler: Kladribin, tüylü hücreli lösemi, tedavi, sağkalım

Address for Correspondence: Esma Evrim Doğan, University of Health Sciences Turkey, Prof. Dr. Cemil Taşcıoğlu City Hospital, Clinic of Hematology, Istanbul, Turkey

Phone: +90 5330291799 E-mail: md.esmaevrimdogan@outlook.com ORCID ID: orcid.org/0000-0003-0635-2966

Cite as: Evrim Doğan E, Demirel N, Turan Erkek E, Aydın Demet, Mansuroğlu I, Cömert Özkan M, Eren R. Treatment Outcomes in Hairy Cell Leukemia: Data of Patients in a Tertiary Referral Hospital in Turkey for Over 20 Years. Med J Bakirkoy 2021;17:320-326 


\section{INTRODUCTION}

Hairy cell leukemia (HCL) is a B cell lymphoproliferative disease that originates from postgerminal central memory cells and splenic marginal zone B cells and is characterized by pancytopenia, splenomegaly, bone marrow involvement accompanied by fibrosis, and the presence of lymphoid cells with cytoplasmic extension (hair-like) in the peripheral blood $(1,2)$. The characteristic immunophenotype of cluster of differentiation (CD)19+, CD20+, CD11C+, CD25+, CD103+, and CD123+ co-expressing cells confirms the diagnostic features of $\mathrm{HCL}$ classic. $\mathrm{HCL}$ constitutes $2 \%$ of all adult leukemias (3). Apart from childhood, the disease can develop in all ages, but is often diagnosed in Caucasian males over 50 years old (4 times more common compared to females) $(1,3)$.

$\mathrm{HCL}$ usually progresses very slowly and current therapies achieve high levels of success (4). Patients who are asymptomatic without progression are followed up without treatment, whereas those symptomatic and those who meet cytopenia criteria receive treatment through a welldefined algorithm of first- and second-line therapy, which includes the use of cladribine (2-chlorodeoxyadenosine, $2 \mathrm{CdA}$ ) and pentostatin (deoxycoformycin). Additional treatment options include splenectomy, interferonalpha (IFN- $\alpha$ ), and chemotherapy, especially as secondline therapy (5). After the introduction of purine analogs (cladribine and pentostatin) as treatment options for $\mathrm{HCL}$, complete remission was demonstrated to be obtained in approximately $75 \%$ of patients, and despite possible relapse within 15 years (50\% of patients), most individuals are likely to have a near-normal life expectancy (6-8).

This retrospective study aimed to analyze the treatment response and adverse effects of treatment, relapses, survival, and occurrence of secondary malignancies in our center during the 24 years of follow-up.

\section{METHODS}

\section{Study Group and Evaluation}

The study group was comprised of all individuals diagnosed with $\mathrm{HCL}$ at Okmeydanı Training and Research Hospital between November 1996 and August 2019. The patients diagnosed with hairy cell variants and those with missing medical files were excluded from the study. Demographic data, clinical features, and treatment-related characteristics and outcomes of 24 patients were recorded from the files and were retrospectively analyzed within the scope of the study.
Bone marrow biopsy results were categorized based on infiltration type (interstitial, diffuse, and both) and degree of fibrosis (scored on a scale from 0 to 4) (9).

\section{Definitions, Treatment Approach, and Response Evaluation}

HCL diagnosis was made according to the World Health Organization criteria based on the results of flow cytometry or bone marrow morphology and immunohistochemistry (10). Treatment is generally initiated in patients with significant cytopenia [Hemoglobin $(\mathrm{Hb})$ of $<11 \mathrm{~g} / \mathrm{dL}, \mathrm{ANC}$ ] of $<1.0 \times 10^{9} / \mathrm{L}$, and/or platelets of $<100 \times 10^{9} / \mathrm{L}$ ), massive or symptomatic splenomegaly, constitutional symptoms (such as fever or night sweats), and/or infections (11).

Splenectomy, IFN- $\alpha$ (referred to as IFN henceforth), cladribine, and rituximab were the treatment options utilized during the 24 years. IFN and splenectomy were preferred as first-line therapy when cladribine was unavailable in Turkey. IFN was started at a dosage of $3 \mathrm{MU}$ three times a week. Splenectomy was performed either laparoscopically or via open surgery. Cladribine was given either by continuous intravenous infusion at $0.1 \mathrm{mg} / \mathrm{kg} /$ day (1-7 days), 2-hour intravenous infusion at $0.1 \mathrm{mg} / \mathrm{kg}$ for 5 consecutive days or once a week for 7 consecutive weeks, or subcutaneously at $0.14 \mathrm{mg} / \mathrm{kg} /$ day for 5 days (12). Rituximab was administered at $375 \mathrm{mg} / \mathrm{m}^{2}$ weekly for four consecutive weeks (13).

The response was evaluated by complete blood count, peripheral blood smear, biochemical parameters, and bone marrow biopsy at 3 months after therapy initiation. Complete response (CR) was defined as (1) the disappearance of hairy cells in the peripheral blood smear and bone marrow, (2) absolute neutrophil count of $>1,500 \times 10^{6} / \mathrm{L}$, platelet of $>100 \times 10^{9} / \mathrm{L}$, and $\mathrm{Hb}$ of $>11 \mathrm{gr} / \mathrm{dL}$, and (3) splenomegaly regression on physical examination. Partial response (PR) was defined as near-normalization of the peripheral blood count (as in CR) with a minimum of $50 \%$ improvement in organomegaly and bone marrow biopsy infiltration with $\mathrm{HCL}$. Relapse was defined as a reappearance of hairy cells in peripheral blood or bone marrow and recurrence of the previously mentioned types of cytopenia or organomegaly or $>50 \%$ increased residual disease after PR. The presence of $P R$ or $C R$ was included in the overall response (OR) evaluations. Any response rather than $\mathrm{PR}$ or $\mathrm{CR}$ was regarded as no response $(14,15)$.

The overall survival was defined as the time from $\mathrm{HCL}$ diagnosis until the death of any cause or the date of the last observation. Relapse-free survival was defined as the time from the treatment initiation until relapse or death, and patients who remained disease-free were censored at the date of the last observation. 


\section{Ethics}

All procedures performed in studies involving human participants were following the ethical standards of the institutional and/or national research committee and with the 1964 Helsinki Declaration and its later amendments or comparable ethical standards. The study was approved by the Clinical Research Ethics Committee of Medical Sciences University, Okmeydanı Training and Research Hospital (approval no: 1387). Informed written consent was obtained from all individual participants who are included in the study.

\section{Statistical Analysis}

The Number Cruncher Statistical System 2007 software was used for all statistical analyses. Research data evaluating presented the descriptive statistics with mean, standard deviation, median, and minimum and maximum values for quantitative data, whereas frequency and percentage were used for categorical data. The Kaplan-Meier survival analysis was used for the survival analyses. The threshold for statistical significance was set at $p<0.05$.

\section{RESULTS}

A total of 24 patients with a median age of 53.5 years were included in the study, wherein $4(16.7 \%)$ were female and 20 (83.3\%) were male. Twelve (50\%) of the patients were incidentally detected and were asymptomatic at the time of diagnosis despite having cytopenia. The characteristics and the presenting features of patients are listed in Table 1.

The laboratory tests evaluation detected neutropenia in 18 patients (66.7\%), pancytopenia in 14 patients (58.3\%). In addition, monocytopenia was detected in 8 patients (33.3\%) out of the 18 patients with available measurements (Table 2). Biopsy findings on bone marrow evaluations are presented in Table 3.

All 24 patients required treatment at presentation, including patients who are asymptomatic but required treatment due to cytopenia. Cladribine was administered to $17(70.8 \%)$ as first-line therapy, wherein 7 (41.2\%) had CR and 10 (58.8\%) had PR. Five patients were given IFN therapy as first-line treatment, wherein 1 patient remained unresponsive and 4 patients had PR. Finally, splenectomy was performed as the first-line therapy in 2 patients, one of which partially responded, whereas the other patient did not attend followup and applied with a relapse later on.

Only 1 (16.7\%) of the 6 patients with CR to cladribine as the first-line treatment required second-line treatment after 4 years. Among the 10 patients with PR to cladribine, 4 required second-line treatment 6-10 years after initial treatment.
Table 1. Characteristics and presenting features of patients with hairy cell leukemia

\begin{tabular}{lll} 
& N & $(\%)$ \\
\hline Median age & $53.5(35-78)$ & \\
\hline Fex & & \\
\hline Male & 4 & $(16.7)$ \\
\hline B symptoms & 20 & $(83.3)$ \\
\hline Weight loss & 3 & $(12.5)$ \\
\hline Night sweating & 2 & $(8.3)$ \\
\hline Fever & 1 & $(4.2)$ \\
\hline Malaise & 1 & $(4.2)$ \\
\hline Fever and infection & 5 & $(20.8)$ \\
\hline Abdominal pain & 3 & $(12.5)$ \\
\hline Bleeding & 3 & $(12.5)$ \\
\hline Ecchymosis & 3 & $(12.5)$ \\
\hline Gingival bleeding & 3 & $(12.5)$ \\
\hline Hematuria & 1 & $(12.5)$ \\
\hline Abdominal swelling & 1 & $(4.2)$ \\
\hline Splenomegaly & 2 & $(8.3)$ \\
\hline
\end{tabular}

\begin{tabular}{lll} 
No & 2 & $(8.3)$ \\
\hline Yes & 22 & $(91.7)$ \\
\hline Mean spleen size, cm & 20.30 & $\pm 5.58 \mathrm{~cm}$ \\
\hline Massive splenomegaly & 10 & $(41.7)$ \\
\hline Hepatomegaly & & \\
\hline No & 11 & $(47.8)$ \\
\hline Yes & 12 & $(52.2)$ \\
\hline
\end{tabular}

Lymphadenopathy

\begin{tabular}{lll} 
No & 18 & $(75.0)$ \\
\hline Yes & 6 & $(25.0)$ \\
\hline Peripheral & 1 & $(16.7)$ \\
\hline Mediastinal & 4 & $(66.7)$ \\
\hline Abdominal & 3 & $(50.0)$ \\
\hline
\end{tabular}

Positive staining

\begin{tabular}{lll} 
CD20 & 19 & $(82.6)$ \\
\hline CD103 & 8 & $(34.8)$ \\
\hline CD11c & 11 & $(47.8)$ \\
\hline CD19 & 6 & $(26.1)$ \\
\hline CD25 & 5 & $(20.8)$ \\
\hline CD38 & 1 & $(4.2)$ \\
\hline
\end{tabular}

CD: Cluster of differantiation 
Table 2. The distribution of peripheral blood parameters

\begin{tabular}{ll} 
Hemoglobin & $\begin{array}{l}\text { Median (minimum- } \\
\text { maximum) }\end{array}$ \\
\hline Platelet & $8.77(4.8-13.8)$ \\
\hline Leukocyte & $48,500(2,000-151,000)$ \\
\hline Absolute neutrophil count & $2,945(1,200-37,940)$ \\
\hline Monocyte count & $600(100-3,790)$ \\
\hline $\begin{array}{l}\text { Hairy cell quantification in peripheral } \\
\text { blood }\end{array}$ & $510(50-29,900)$ \\
\hline & $17(8-50)$ \\
\hline Hairy cell in peripheral blood & $\mathrm{N}$ \\
\hline No & 18 \\
\hline Yes & 6 \\
\hline
\end{tabular}

Table 3. Bone marrow biopsy findings

\begin{tabular}{lll} 
& N & (\%) \\
\hline Infiltration type & 24 & $(100)$ \\
\hline Diffuse & 12 & $(50.0)$ \\
\hline Interstitial & 7 & $(29.2)$ \\
\hline Diffuse + interstitial & 3 & $(12.5)$ \\
\hline Unknown & 2 & $(8.3)$ \\
\hline Degree of fibrosis & 24 & $(100)$ \\
\hline Not checked & 2 & $(8.3)$ \\
\hline 1/4 & 2 & $(8.3)$ \\
\hline 2/4 & 11 & $(45.83)$ \\
\hline 3/4 & 9 & $(37.5)$ \\
\hline TRAP positivity & 24 & $(100)$ \\
\hline Unchecked & 1 & $(8.3)$ \\
\hline Positive & 23 & $(91.7)$ \\
\hline TRAP: Tartrate-resistant acid phosphatase & & \\
\hline
\end{tabular}

Overall progression-free survival after first-line therapy was $83.58 \pm 57.40$ months. In cases where cladribine was administered, 12 (70.6\%) were progression-free and 5 had a relapse and the mean progression-free survival time was $142.91 \pm 16.69$ months. In cases where cladribine was not administered, 1 patient (14.3\%) was progression-free and 6 had a relapse and the mean progression-free survival time was $78.07 \pm 24$ months. The progression-free survival analysis via the log-rank test revealed a significantly shorter progression-free survival rate in patients who did not receive cladribine as first-line therapy $(p<0.001)$.
A total of 11 patients received second-line therapy. Ten patients received cladribine, of which $6(60 \%)$ had CR and 4 (40\%) had PR. The overall median progression-free survival time after the second-line therapy was 126.39 months, whereas 73.8 months for cladribine recipients.

Among 2 patients who had PR to cladribine therapy in the second-line treatment, 1 was given rituximab with $C R$, whereas cladribine therapy was repeated in the other, which resulted in PR (Table 4).

Approximately 2 years after IFN treatment, 1 patient who was partially responsive developed osteomyelitis. Four of the patients $(16.67 \%)$ had concomitant malignancy (basal-cell carcinoma, ureteral adenocarcinoma, laryngeal adenocarcinoma, and prostatic adenocarcinoma), wherein 1 was detected before treatment (prostatic adenocarcinoma), secondary malignancy was detected in 2 patients after cladribine treatment and 1 after IFN therapy.

As a complication of cladribine treatment, 5 patients developed febrile neutropenia and responded to antibiotherapy and G-CSF treatment. Two of the patients died due to concomitant secondary malignancies. As of writing, 22 of the 24 patients (91.7\%) are still alive. Overall, the final data showed that mean survival was $132.58 \pm 16.98$ months and mean follow-up duration was $130.77 \pm 75.07$ months (Table 5, Figure 1-3).

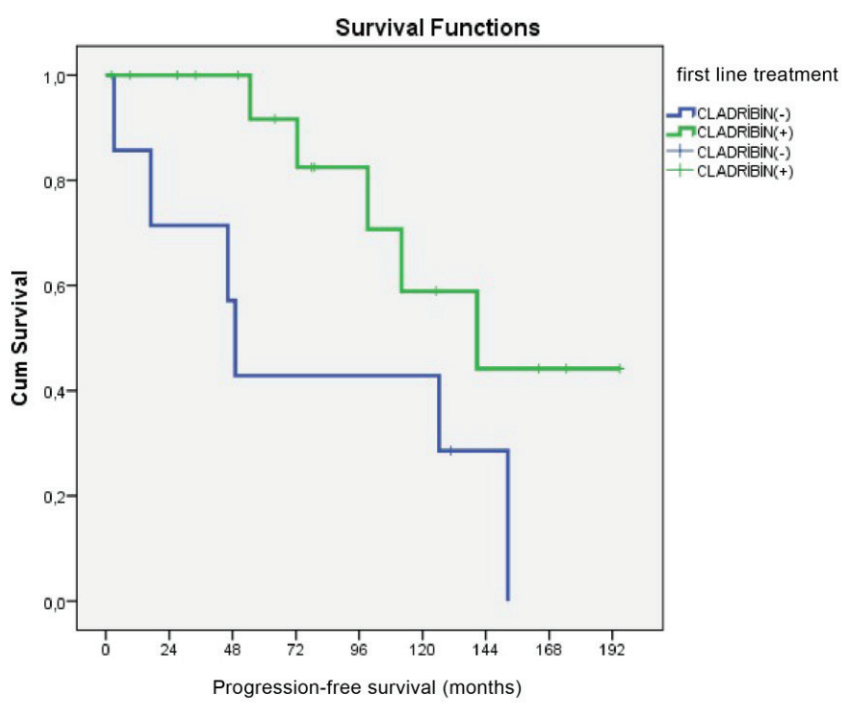

Figure 1. Kaplan-Meier curve of progression-free survival according to cladribine used in first-line treatment

\section{DISCUSSION}

The current study provides additional data demonstrating the efficacy of available treatment modalities in patients 


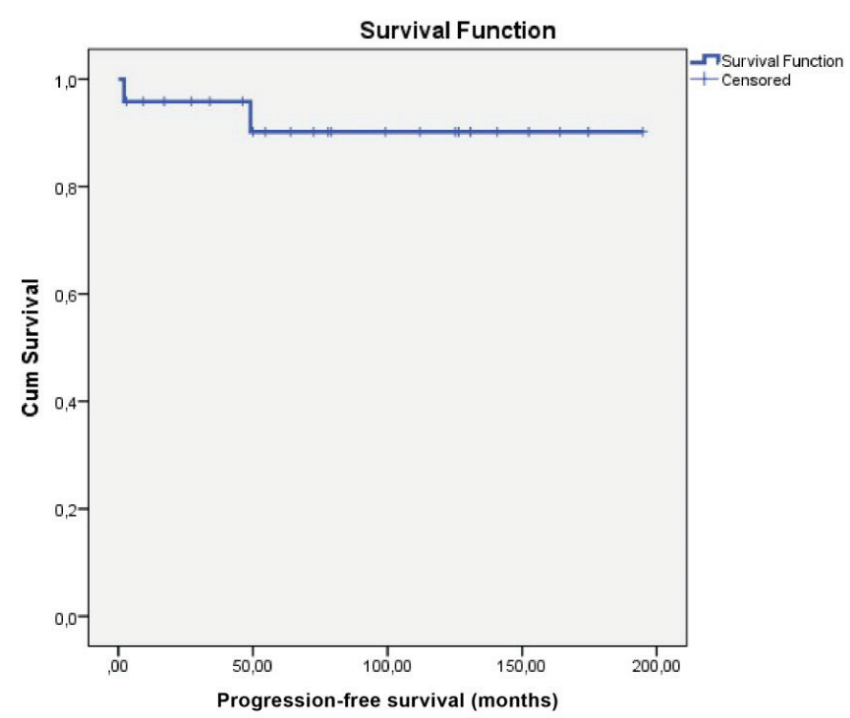

Figure 2. Kaplan-Meier curve of progression-free survival after first and second-line treatment

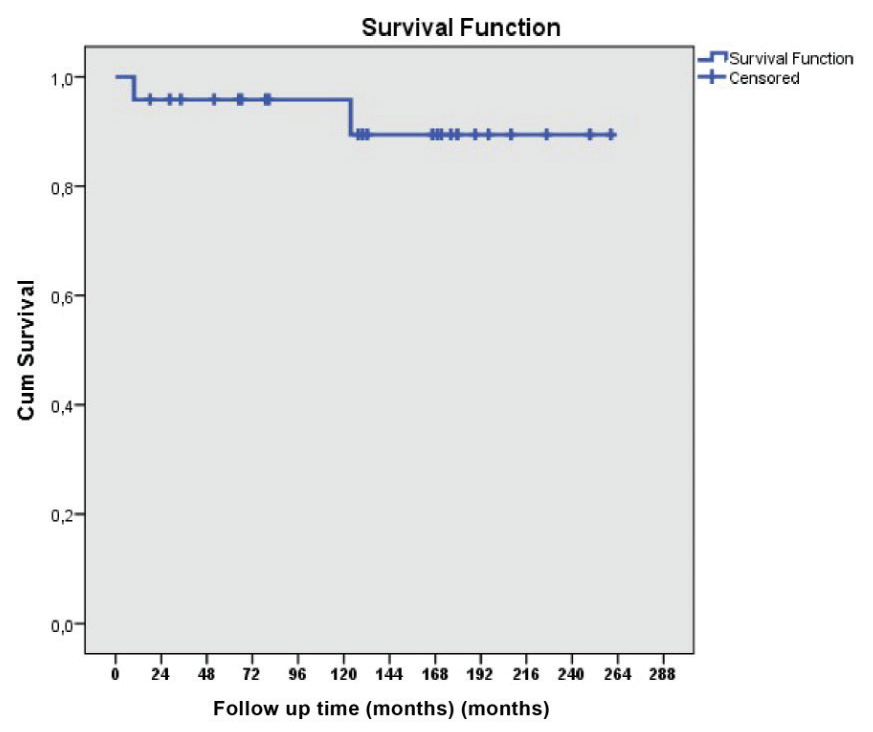

Figure 3. Kaplan-Meier curve for overall survival

with $\mathrm{HCL}$, especially for cladribine therapy that yielded a significantly longer progression-free survival and reduced the frequency of relapse compared to patients who had not received cladribine as first-line therapy. Of note, all patients responded to cladribine; however, CR was observed in only $41.2 \%$ of patients.

The study conducted by Mikler Mascarenhas (7) (12 patients) revealed a treatment response to cladribine from all participants, and the CR rate was $92 \%$. The literature reported frequencies ranging from $75 \%$ to $100 \%$ CR to cladribine in large-scale series $(16,17)$. This situation was attributed to the presence of severe thrombocytopenia, massive splenomegaly, or multiple lymphadenopathies in our cases.
The literature focusing on the clinical findings of patients with $\mathrm{HCL}$ show that the most frequently identified examination findings are splenomegaly (60-90\%) and cytopenia (anemia, leukopenia, neutropenia, thrombocytopenia, and monocytopenia with frequencies of $70 \%, 65 \%, 75 \%, 80 \%$, and $90 \%$, respectively) $(14,18,19)$. Our study found anemia in $91.7 \%$ of patients, leukopenia in $62.5 \%$, neutropenia in $66.7 \%$, thrombocytopenia in $95.8 \%$, and monocytopenia in $33.3 \%$. Findings other than monocytopenia were very similar in frequency to values reported in the literature. The lower frequency of monocytopenia may be in part due to the initial monocyte levels that were not determined in 6 patients. Even so, tartrate-resistant acid phosphatase positivity was present in $100 \%$ of our patients and all were diagnosed with typical HCL; therefore, even if all of these 6 individuals had monocytopenia, there would still be a considerable difference compared to studies reporting data from patients with typical HCL.

In the 2000 update of the $\mathrm{HCL}$ guideline published by the British Society for Hematology, the severity of cytopenia was reported to depend on spleen size and extensive bone marrow infiltration (20). Pancytopenia was determined in 14 of our patients (58.3\%), 22 (91.7\%) had splenomegaly, and 15 (62.5\%) had diffuse bone marrow infiltration. Pancytopenia and splenomegaly ratios in our study are very similar to those reported by Chatterjee et al. (21); however, their results are higher than those reported in other literature $(2,4)$.

Lymphadenopathy was detected in 25\% ( $n=6)$ of our 24 patients, and it was reported to be within $9 \%-20 \%$ in the literature (4,6,21-23). In our series, 3 patients had mediastinal, 2 had intra-abdominal multiple lymphadenopathies, and 1 had extensive and conglomerate lymphadenopathy. In another patient, extensive lymphadenopathy involvement was observed in the axillary, mediastinal, and intraabdominal regions. All three patients with mediastinal lymphadenopathy partially responded to cladribine treatment. These lymph nodes were not extensively affected (and did not exceed $2 \mathrm{~cm}$ ), which suggests that mediastinal localization may have a negative effect on treatment response. Among the patients with extensive multiple intra-abdominal lymphadenopathies, those with extensive conglomerate lymphadenopathy partially responded to cladribine, whereas the others demonstrated CR. This suggests that the extent and size of the intraabdominal lymph node involvement may be more important than localization. Indeed, in a study of 88 cases in which Mercieca et al. (24) investigated the frequency of abdominal lymphadenopathy in $\mathrm{HCL}$, the presence of abdominal lymphadenopathy was found to be associated 
Table 4. Distribution of first-line treatments and treatment response

\begin{tabular}{|c|c|c|c|c|}
\hline First-line treatments & $\begin{array}{l}\text { Interferon a } \\
(n=5,20.8 \%)\end{array}$ & $\begin{array}{l}\text { Cladribine } \\
(n=17,70.8 \%)\end{array}$ & $\begin{array}{l}\text { Splenectomy } \\
(n=2,8.3 \%)\end{array}$ & $\begin{array}{l}\text { Total } \\
(n=24,100 \%)\end{array}$ \\
\hline Unresponsive, n (\%) & $1(20 \%)$ & 0 & 0 & $1(4.2 \%)$ \\
\hline Partial response, n (\%) & $4(80 \%)$ & $10(58.8 \%)$ & $1(50 \%)$ & 15 (62.5\%) \\
\hline Complete response, n (\%) & 0 & $7(41.2 \%)$ & 0 & $7(29.2 \%)$ \\
\hline No follow-up, n (\%) & 0 & 0 & $1(50 \%)$ & $1(4.2 \%)$ \\
\hline
\end{tabular}

Table 5. Survival analyses according to the use of cladribine as first-line treatment

\begin{tabular}{|c|c|c|c|}
\hline & $\begin{array}{l}\text { Cladribine }(+) \\
(n=17,70.8 \%)\end{array}$ & $\begin{array}{l}\text { Cladribine }(-) \\
(n=7,29.2 \%)\end{array}$ & $p$ \\
\hline Patients with relapse & 5 (29.4\%) & $6(85.7 \%)$ & \\
\hline $\begin{array}{l}\text { Patients with } \\
\text { progression-free } \\
\text { survival }\end{array}$ & $12(70.6 \%)$ & $1(14.3 \%)$ & 0.012 \\
\hline $\begin{array}{l}\text { Mean progression- } \\
\text { free survival, months }\end{array}$ & $142.91 \pm 16.69$ & $78.07 \pm 24.53$ & $<0.001$ \\
\hline
\end{tabular}

with treatment resistance. In an earlier publication by the same author that included 12 cases with $\mathrm{HCL}$ who had abdominal lymphadenopathy, abdominal imaging was stated to be necessary at the time of diagnosis (25).

No staging system for $\mathrm{HCL}$ has yet been defined in the literature. However, considering that our patients had more frequent splenomegaly and pancytopenia at presentation, the increased frequency and the extent of lymphadenopathy involvement may suggest that patients were admitted with relatively advanced disease. However, larger case series need to be evaluated to define "advanced disease" and to claim that lymph node involvement may be more frequent in such patients. These studies will also be important to determine whether the localization of lymphadenopathy has any influence on treatment response.

Similar to the study of Öngören et al. (26), our study found a significantly lower frequency of progressive disease in patients who received cladribine as first-line treatment compared to those who received splenectomy or IFN treatment. The mean follow-up time of patients was $130.77 \pm 75.07$ months, the mean progression-free survival after the first-line cladribine treatment was $142.91 \pm 16.69$ months (median: 77.96 months). These values were found to be longer than those reported by other domestic studies, but shorter than that of the 233-case study by Else et al. $(27)(6,26)$. After the second-line therapy, the OR to cladribine was again $100 \%$, while the CR rate was $60 \%$. Higher CR rates after relapse were thought to be due to a lower frequency of lymph node involvement and massive splenomegaly at the time of relapse. Mean progression-free survival after second-line treatment was $83.45 \pm 66.82$ months (median 73.8 months), again shorter compared to the study by Else et al. (27); however, studies have repeatedly shown that severe anemia and severe thrombocytopenia are associated with decreased survival (17). Therefore, the difference may be due to the presence of higher median hemoglobin and platelet levels at the time of diagnosis in the study by Else et al. (27).

The rarity of $\mathrm{HCL}$, the single-center nature of our data, and the number of patients included in the study are notable limitations, which must be considered when concluding our results. Furthermore, even though clinical data deficits were minimal, the presence of missing data and the insufficient measurements in all patients may further hamper the accuracy of laboratory-related findings.

\section{CONCLUSION}

Finally, the lack of $\beta 2$-microglobulin and BRAF mutation analysis is an important limitation.

Such high lymph node involvement at the time of diagnosis in our group of patients seems remarkable, and therefore, is believed to be a factor that reduced cladribine response. The effects of the presence of abdominal multiple lymphadenopathies, occurring particularly due to relapse, on the treatment response has been investigated in the literature; however, large-scale studies are needed to evaluate the effects of extensive lymph node involvement and its localization in the early phase, especially for its influence on therapy response and survival.

\section{ETHICS}

Ethics Committee Approval: The study was approved by the Clinical Research Ethics Committee of Medical Sciences University, Okmeydani Training and Research Hospital (approval no: 1387).

Informed Consent: Informed written consent was obtained from all individual participants who are included in the study.

\section{Authorship Contributions}

Surgical and Medical Practices: E.E.D., D.A., R.E., Concept: E.E.D., N.D., D.A., Design: E.E.D., I.M., R.E., Data Collection 
or Processing: N.D., E.T.E., M.C.Ö., Analysis or Interpretation: E.T.E., D.A., M.C.Ö., Literature Search: E.E.D., N.D., E.T.E., I.M., Writing: E.E.D., N.D., I.M., R.E.

Conflict of Interest: No conflict of interest was declared by the authors.

Financial Disclosure: The authors declared that this study received no financial support.

\section{REFERENCES}

1. Robak T, Matutes E, Catovsky D, Zinzani PL, Buske C; ESMO Guidelines Committee. Hairy cell leukaemia: ESMO Clinical Practice Guidelines for diagnosis, treatment and follow-up. Ann Oncol 2015;26 Suppl 5:v100-7.

2. Troussard X, Cornet E. Hairy cell leukemia 2018: Update on diagnosis, risk-stratification, and treatment. Am J Hematol 2017:92:1382-90.

3. Gürman G. Lenfoplazmasitik Lenfoma. HematoLog: Türk Hematoloji Derneği 2013;3:271-5.

4. Somasundaram V, Purohit A, Aggarwal M, Manivannan P, Mishra $P$, Seth $T$, et al. Hairy cell leukemia: A decade long experience of North Indian Hematology Center. Indian J Med Paediatr Oncol 2014;35:271-5.

5. Lauria Af G, Raspadori D. The Therapy of Hairy Cell Leukemia: The State of Art. Ann Hematol Oncol 2015;2:1035.

6. Erkut N, Batur DS, Akidan O, Karabacak V, Sönmez M. Tüylü Hücreli Lösemili Hastaların Uzun Dönem Tedavi Sonuçları: Tek Merkez Deneyimi. Türkiye Klinikleri Tip Bilimleri Dergisi 2018;38:236-40.

7. Mikler E, Mascarenhas J. Current therapeutic options in hairy cell leukemia. J Community Support Oncol 2014;12:104-8.

8. Liu Q, Harris N, Epperla N, Andritsos LA. Current and Emerging Therapeutic Options for Hairy Cell Leukemia Variant. Onco Targets Ther 2021;14:1797-805.

9. Bain BJ, Clark DM, Wilkins BS. Bone marrow pathology: John Wiley \& Sons, 2019

10. Norris D, Stone J. WHO classification of tumours of haematopoietic and lymphoid tissues. Geneva: WHO. 2008:188-90.

11. Thompson PA, Ravandi F. How I manage patients with hairy cell leukaemia. Br J Haematol 2017;177:543-56.

12. Benz R, Arn K, Andres M, Pabst T, Baumann M, Novak U, et al. Prospective long-term follow-up after first-line subcutaneous cladribine in hairy cell leukemia: a SAKK trial. Blood Adv 2020;4:3699-707.

13. Leclerc M, Suarez F, Noël MP, Vekhoff A, Troussard X, Claisse JF, et al. Rituximab therapy for hairy cell leukemia: a retrospective study of 41 cases. Ann Hematol 2015;94:89-95.
14. Grever MR, Abdel-Wahab O, Andritsos LA, Banerji V, Barrientos J, Blachly JS, et al. Consensus guidelines for the diagnosis and management of patients with classic hairy cell leukemia. Blood 2017:129:553-60.

15. Andrasiak I, Rybka J, Wrobel T. Response to the Therapy in Hairy Cell Leukemia: Systematic Review and Meta-Analysis. Clin Lymphoma Myeloma Leuk 2018;18:392-9.e3.

16. Maevis $V$, Mey U, Schmidt-Wolf G, Hairy cell leukemia: short review, today's recommendations and outlook. Blood Cancer J 2014;4:e184.

17. Grever MR. How I treat hairy cell leukemia. Blood 2010;115:21-8.

18. Delrieu V, Springael C, Wu K, Verhoef G, Janssens A. BHS guidelines for the diagnosis and the treatment of hairy cell leukaemia. Belg J Hematol 2017;8:222-8.

19. Parry-Jones N, Joshi A, Forconi F, Dearden C; BSH guidelines committee. Guideline for diagnosis and management of hairy cell leukaemia (HCL) and hairy cell variant (HCL-V). Br J Haematol 2020;191:730-7.

20. Catovsky D. On behalf of the Clinical Task Force of the British Committee for Standards in Haematology. Hairy cell leukaemia. Guidelines on diagnosis and therapy. 2000.

21. Chatterjee T, Panigrahi I, Mahapatra M, Pati HP, Kumar R, Naithani $R$, et al. Hairy cell leukemia: clinical, pathological and ultrastructural findings in Asian-Indians. Indian J Cancer 2008;45:41-4.

22. Hilmi Erdem G, Vildan O, Zafer Serenli Y, Vildan G, Ridvan A, Fahir O. Hairy Cell Leukemia: A Single-Center Experience. LLM Dergi 2017;1:85-91.

23. Matutes E. Diagnostic and therapeutic challenges in hairy cell leukemia-variant: where are we in 2021? Expert Rev Hematol 2021;14:355-63.

24. Mercieca J, Puga M, Matutes E, Moskovic E, Salim S, Catovsky D. Incidence and significance of abdominal lymphadenopathy in hairy cell leukaemia. Leuk Lymphoma 1994;14 Suppl 1:79-83.

25. Mercieca J, Matutes E, Moskovic E, MacLennan K, Matthey F, Costello $\mathrm{C}$, et al. Massive abdominal lymphadenopathy in hairy cell leukaemia: a report of 12 cases. Br J Haematol 1992;82:547-54.

26. Öngören Ş, Eşkazan AE, Berk S, Elverdi T, Salihoğlu A, Ar MC, et al. Retrospective Evaluation of Hairy Cell Leukemia Patients Treated with Three Different First-Line Treatment Modalities in the Last Two Decades: A Single-Center Experience. Turk J Haematol 2017:34:291-9.

27. Else M, Dearden CE, Matutes E, Garcia-Talavera J, Rohatiner AZ, Johnson SA, et al. Long-term follow-up of 233 patients with hairy cell leukaemia, treated initially with pentostatin or cladribine, at a median of 16 years from diagnosis. Br J Haematol 2009;145:733-40. 